\title{
Characterisation of Pasteurella multocida isolates from pigs with pneumonia in Korea
}

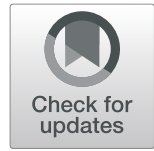

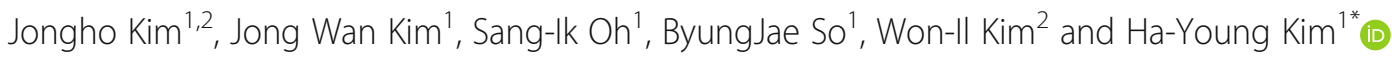

\begin{abstract}
Background: Pasteurella multocida is responsible for significant economic losses in pigs worldwide. In clinically diseased pigs, most $P$. multocida isolates are characterised as subspecies multocida, biovar 2 or 3 and capsular type A or D; however, there is little information regarding subspecies, biovars, and other capsular types of $P$. multocida isolates in Korea. Here, we provided information covering an extended time period regarding $P$. multocida in pigs with pneumonia in Korea using phenotypic and genotypic characterisations and data associated with the minimum inhibitory concentrations.

Results: The overall prevalence of $P$. multocida between 2008 and 2016 was 16.8\% (240/1430), with 85\% of the $P$. multocida isolates (204/240) coinfected with other respiratory pathogens. Of the 240 isolates, 166 were included in this study; all of these $P$. multocida isolates were characterised as subspecies multocida and the most prevalent phenotypes were represented by biovar $3(68.7 \% ; n=114)$ and capsular type A $(69.9 \% ; n=116)$. Additionally, three capsular type F isolates were identified, with this representing the first report of such isolates in Korea. All biovar 1 and 2 isolates were capsular types $F$ and $A$, respectively. The virulence-associated gene distribution was variable; all capsular type A and D isolates harboured pmHAS and hsf-1, respectively $(P<0.001$ ), with type $F$ (biovar 1$)$ significantly correlated with hsf-1 $(P$ $<0.05)$ and $p f h A(P<0.01)$, biovar 2 highly associated with $p f h A$ and $p m H A S$, and biovar 3 significantly correlated with hsf-1, pmHAS, and hgbB $(P<0.001)$, whereas biovar 13 was related only to $h g b B(P<0.05)$. The highest resistance rate was found to be to oxytetracycline (63.3\%), followed by florfenicol (16.3\%).

Conclusions: P. multocida subspecies multocida, biovar 3, and capsular type A was the most prevalent isolate in this study, and our findings indicated the emergence of capsular type F in Korea. Moreover, prudent use of oxytetracycline and florfenicol is required because of the identified high resistance rates. Further studies are required for continuous monitoring of the antimicrobial resistance, prevalence, and epidemiological characterisation of P. multocida, and experimental infection models are needed to define the pathogenicity of capsular type $F$.
\end{abstract}

Keywords: Antimicrobial resistance, Biovar, Capsular type, Pasteurella multocida, Virulence-associated gene

\section{Background}

Pasteurella multocida (P. multocida) is a commensal and opportunistic pathogen of the oral, nasopharyngeal, and upper respiratory tract [1] and the causative agent of a wide range of infections leading to high economic impact [2]. In pigs, P. multocida is associated with progressive atrophic rhinitis (PAR), and together with other respiratory pathogens, plays a significant role in porcine respiratory disease complex (PRDC) [3-6]. P. multocida prevalence has been reported as $8.0 \%$ in diseased pigs

\footnotetext{
*Correspondence: kimhy@korea.kr; jnm4jesus@naver.com

${ }^{1}$ Animal Disease Diagnostic Division, Animal and Plant Quarantine Agency,

177 Hyeoksin 8-ro, Gimcheon, Gyeongbuk 39660, Republic of Korea

Full list of author information is available at the end of the article
}

with pneumonia or PAR in China, and from 10.3 to $15.6 \%$ in pigs with pneumonia in Korea. Additionally, $P$. multocida constitutes $15.6 \%$ of isolated respiratory pathogens in the United States $[3,5,7,8]$.

P. multocida can be divided into three subspecies (multocida, septica, and gallicida) and 13 biovars (1-10 and 12-14) based on carbohydrate fermentation and production of the ornithine decarboxylase (ODC) enzyme [9-11]. The majority of swine isolates are subspecies multocida and mostly assigned as biovars 2 or $3[1$, $10,12,13]$. Additionally, five capsular types based on capsular antigens (A, B, D, E, and F) have been described in P. multocida, with capsular types $\mathrm{A}, \mathrm{B}, \mathrm{D}$, and $\mathrm{F}$ recovered from swine $[1,14]$. Capsular types $\mathrm{A}$ and $\mathrm{D}$ are

(c) The Author(s). 2019 Open Access This article is distributed under the terms of the Creative Commons Attribution 4.0 International License (http://creativecommons.org/licenses/by/4.0/), which permits unrestricted use, distribution, and 
Table 1 Primers used for the detection of capsular types and virulence-associated genes in Pasteurella multocida isolates

\begin{tabular}{|c|c|c|c|c|c|}
\hline Gene function & Target gene & Description & Sequence $\left(5^{\prime}-3^{\prime}\right)$ & size (bp) & Reference \\
\hline \multirow[t]{6}{*}{ Capsule serotypes } & kmtl & $\begin{array}{l}\text { Identification of all } \\
\text { P. multocida isolates }\end{array}$ & $\begin{array}{l}\text { ATCCGCTATTTACCCAGTGG } \\
\text { GCTGTAAACGAACTCGCCAC }\end{array}$ & 460 & [19] \\
\hline & hyaD-hyac & Serogroup A cap gene & $\begin{array}{l}\text { TGCCAAAATCGCAGTGAG } \\
\text { TTGCCATCATTGTCAGTG }\end{array}$ & 1044 & {$[20]$} \\
\hline & $b c b D$ & Serogroup B cap gene & $\begin{array}{l}\text { CATTTATCCAAGCTCCACC } \\
\text { GCCCGAGAGTITCAATCC }\end{array}$ & 760 & [20] \\
\hline & $d c b F$ & Serogroup D cap gene & $\begin{array}{l}\text { TTACAAAAGAAAGACTAGGAGCCC } \\
\text { CATCTACCCACTCAACCATATCAG }\end{array}$ & 657 & [20] \\
\hline & ecbJ & Serogroup E cap gene & $\begin{array}{l}\text { TCCGCAGAAAATTATTGACTC } \\
\text { GCTTGCTGCTTGATTITGTC }\end{array}$ & 511 & [20] \\
\hline & $f c b D$ & Serogroup F cap gene & $\begin{array}{l}\text { AATCGGAGAACGCAGAAATCAG } \\
\text { TTCCGCCGTCAATTACTCTG }\end{array}$ & 851 & {$[20]$} \\
\hline \multirow[t]{4}{*}{$\begin{array}{l}\text { Outer membrane } \\
\text { and porin proteins }\end{array}$} & oma87 & Outer membrane protein 87 & $\begin{array}{l}\text { ATGAAAAAACTTITAATTGCGAGC } \\
\text { TGACTTGCGCAGTTGCATAAC }\end{array}$ & 948 & {$[17]$} \\
\hline & $\mathrm{ompH}$ & Outer membrane protein $\mathrm{H}$ & $\begin{array}{l}\text { CGCGTATGAAGGTTAGGT } \\
\text { TITAGATTGTGCGTAGTCAAC }\end{array}$ & 438 & {$[17]$} \\
\hline & $p l p B$ & Outer membrane protein & $\begin{array}{l}\text { TTGGTGGTGCGTATGTCTTCT } \\
\text { AGTCACTITAGATTGTGCGTAG }\end{array}$ & 282 & [18] \\
\hline & psl & Porin protein & $\begin{array}{l}\text { TCTGGATCCATGAAAAAACTAACTAAAGTA } \\
\text { AAGGATCCTTAGTATGCTAACACAGGACGACG }\end{array}$ & 470 & {$[17]$} \\
\hline \multirow[t]{5}{*}{ Adhesins } & $\operatorname{fim} A$ & Fimbriae & $\begin{array}{l}\text { CCATCGGATCTAAACGACCTA } \\
\text { AGTATTAGTTCCTGCGGGTG }\end{array}$ & 866 & {$[18]$} \\
\hline & pfhA & Filamentous haemagglutinin & $\begin{array}{l}\text { AGCTGATCAAGTGGTGAAC } \\
\text { TGGTACATTGGTGAATGCTG }\end{array}$ & 275 & {$[21]$} \\
\hline & $p t f A$ & Fimbriae & $\begin{array}{l}\text { TGTGGAATTCAGCATTITAGTGTGTC } \\
\text { TCATGAATTCTTATGCGCAAAATCCTGCTGG }\end{array}$ & 488 & [17] \\
\hline & hsf-1 & Autotransporter adhesion & $\begin{array}{l}\text { TTGAGTCGGCTGTAGAGTTCG } \\
\text { ACTCTITAGCAGTGGGGACAACCTC }\end{array}$ & 654 & [18] \\
\hline & hsf-2 & Autotransporter adhesion & $\begin{array}{l}\text { ACCGCAACCATGCTCTTAC } \\
\text { TGACTGACATCGGCGGTAC }\end{array}$ & 433 & {$[18]$} \\
\hline \multirow[t]{2}{*}{$\begin{array}{l}\text { Superoxide } \\
\text { dismutases }\end{array}$} & $\operatorname{sod} A$ & Superoxide dismutases & $\begin{array}{l}\text { TACCAGAATTAGGCTACGC } \\
\text { GAAACGGGTTGCTGCCGCT }\end{array}$ & 361 & {$[17]$} \\
\hline & sodC & Superoxide dismutases & $\begin{array}{l}\text { AGTTAGTAGCGGGGTTGGCA } \\
\text { TGGTGCTGGGTGATCATCATG }\end{array}$ & 235 & [17] \\
\hline \multirow[t]{6}{*}{$\begin{array}{l}\text { Iron acquisition } \\
\text { related factor }\end{array}$} & $\operatorname{exbB}$ & $\begin{array}{l}\text { Iron regulated and } \\
\text { acquisition factors }\end{array}$ & $\begin{array}{l}\text { TTGGCTTGTGATTGAACGC } \\
\text { TGCAGGAATGGCGACTAAA }\end{array}$ & 283 & [18] \\
\hline & exbBD-tonB & $\begin{array}{l}\text { Iron acquisition related } \\
\text { factors }\end{array}$ & $\begin{array}{l}\text { GGTGGTGATATTGATGCGGC } \\
\text { GCATCATGCGTGCACGGTT }\end{array}$ & 1144 & {$[17]$} \\
\hline & fur & $\begin{array}{l}\text { Iron regulated and } \\
\text { acquisition factors }\end{array}$ & $\begin{array}{l}\text { GTTACCGTGTATTAGACCA } \\
\text { CATTACTACATTTGCCATAC }\end{array}$ & 244 & [18] \\
\hline & tbpa & Iron acquisition related factor & $\begin{array}{l}\text { TGGTTGGAAACGGTAAAGC } \\
\text { TAACGTGTACGGAAAAGCC }\end{array}$ & 728 & {$[21]$} \\
\hline & $h g b A$ & $\begin{array}{l}\text { Haemoglobin binding } \\
\text { protein }\end{array}$ & $\begin{array}{l}\text { TGGCGGATAGTCATCAAG } \\
\text { CCAAAGAACCACTACCCA }\end{array}$ & 419 & [17] \\
\hline & $h g b B$ & Haemoglobin binding protein & $\begin{array}{l}\text { TCATTGAGTACGGCTTGAC } \\
\text { CTTACGTCAGTAACACTCG }\end{array}$ & 499 & {$[21]$} \\
\hline \multirow[t]{2}{*}{ Neuraminidases } & $\operatorname{nan} B$ & Neuraminidases & $\begin{array}{l}\text { GTCCTATAAAGTGACGCCGA } \\
\text { ACAGCAAAGGAAGACTGTCC }\end{array}$ & 554 & [17] \\
\hline & nanH & Neuraminidases & $\begin{array}{l}\text { GAATATTTGGGCGGCAACA } \\
\text { TTCTCGCCCTGTCATCACT }\end{array}$ & 360 & [17] \\
\hline Hyaluronidase & PMHAS & Hyaluronidase & $\begin{array}{l}\text { TCAATGTTGGCGATAGTCCGTTAG } \\
\text { TGGCGAATGATCGGTGATAGA }\end{array}$ & 430 & [18] \\
\hline Toxin & toxA & Dermonecrotic toxin & $\begin{array}{l}\text { TCTTAGATGAGCGACAAGG } \\
\text { GAATGCCACACCTCTATAG }\end{array}$ & 846 & [21] \\
\hline
\end{tabular}


most commonly cultured from pneumonic lungs and PAR, respectively, whereas capsular types $\mathrm{B}$ and $\mathrm{F}$ are rarely isolated from pigs [3, 14-16]. In Korea, numerous studies suggest that capsular type A is more prevalent in porcine pneumonia than type $\mathrm{D}[7,8,15]$; however, limited information is available regarding subspecies, biovars, and other capsular types of P. multocida isolates in Korea.

P. multocida reportedly possesses various virulence factors that play a significant role in pasteurellosis and survival in the host environment $[3,17,18]$. Furthermore, there is a clear correlation between certain virulence factors and capsular types or biovars $[1,3]$. The functions and target genes of these factors are detailed in Table 1 and include those encoding outer membrane and porin proteins (oma87, ompH, plpB, and psl), adhesins (fimA, pfhA, ptfA, hsf-1, and hsf-2), superoxide dismutases $(\operatorname{sod} A$ and $\operatorname{sod} C)$, iron-acquisition-related factors (exbB, exbBD-tonB, fur, tbp $A$, $h g b A$, and $h g b B$ ), neuraminidases (nanB and nanH), hyaluronidase ( $m$ mHAS), and toxin (toxA). Identifying which virulence factors are prevalent is necessary to predict the pathogenic behaviour of the isolates and select potential future vaccine candidates.

Antimicrobial resistance in pathogenic bacteria from food animals and the environment has become a global public health issue. Although beta-lactams, trimethoprim combination, florfenicol, macrolides, and tetracyclines have been shown to be the best antimicrobials for treating PRDC [6], resistance to these antimicrobials has been detected previously in $P$. multocida in many countries [3, 22-24]. In Korea, $P$. multocida isolates from pigs are sensitive to most antimicrobial agents, including ampicillin, ceftiofur, tilmicosin, and enrofloxacin, other than tiamulin [7].

To the best of our knowledge, only short-term studies have been performed to characterise porcine $P$. multocida isolates in Korea. This long-term study was carried out to provide baseline information regarding a large collection of $P$. multocida isolates from clinically diseased pigs by determining the distribution and association of capsular types, biovars, extensive virulence-associated gene profiles, and antimicrobial-resistance patterns.

\section{Results}

Prevalence of $P$. multocida in porcine pneumonic lungs In total, $240 \mathrm{P}$. multocida isolates $(16.8 \%)$ were recovered (Table 2); P. multocida was the second most frequently isolated bacterial pathogen in this study. Most isolates $(85.0 \%$; 204/240) were detected simultaneously with other respiratory pathogens, such as porcine reproductive and respiratory syndrome virus (PRRSV; 61.3\%), porcine circovirus type 2 (PCV2; 37.5\%), or Streptococcus suis (S. suis; 20.0\%). Mycoplasma hyorhinis (MHR), Actinobacillus pleuropneumoniae (APP), Mycoplasma hyopneumoniae (MHP), Haemophilus parasuis (HPS), Trueperella pyogenes (T. pyogenes), and swine influenza virus (SIV) were detected to a lesser extent (19.2, 14.2, $10.4,10.0,4.6$, and $3.8 \%$, respectively). Of the P. multocida isolates, 166 were included in this study.

\section{Subspecies, biovar, and capsular type determination}

The distribution of biovars and capsular types among the studied P. multocida isolates is shown in Table 3. All 166 isolates were identified as $P$. multocida subspecies multocida, which produces acid from sorbitol and glucose but not from dulcitol, lactose, and maltose. Most ODC-producing isolates belonged to biovar 3 (68.7\%), followed by biovars $2(21.1 \%)$ and $1(1.8 \%)$. Interestingly, 14 isolates $(8.4 \%)$ displayed identical carbohydrate fermentation results to biovar 3, except for ODC activity, and were thus assigned to biovar 13. All biovar 1 and 2 isolates comprised capsular type $\mathrm{F}$ and $\mathrm{A}$, respectively $(P<0.001)$, whereas biovar 3 isolates comprised capsular types $\mathrm{A}$ and $\mathrm{D}(P<0.001)$, and biovar 13 comprised capsular types A and D $(P>0.05)$. Capsular type A $(69.9 \%)$ isolates were the most prevalent, followed by types $D$ $(28.3 \%)$ and $\mathrm{F}(1.8 \%)$, with none of the isolates in this study identified as type B or E. Importantly, this is the first report of capsular type $\mathrm{F} /$ biovar 1 isolation since 2014 (Table 3).

\section{Distribution of virulence-associated genes}

Results of polymerase chain reaction (PCR) analysis of 21 virulence-associated genes showed that all $P$. multocida isolates harboured 14 genes (oma87, ompH, $p \operatorname{lp} B$, psl, fimA, hsf-2, sodA, $\operatorname{sod} C, \operatorname{exbB}$, ExbBD-tonB, fur,

Table 2 Prevalence of respiratory pathogens and the frequency of Pasteurella multocida co-infection with other pathogens

\begin{tabular}{|c|c|c|c|c|c|c|c|c|c|c|c|c|}
\hline & \multirow{2}{*}{$\begin{array}{l}\text { No. of } \\
\text { sample }\end{array}$} & \multicolumn{7}{|c|}{ Bacteria $^{a}$} & \multicolumn{3}{|l|}{ Virus $^{b}$} & \multirow[t]{2}{*}{ None $^{c}$} \\
\hline & & $\overline{\mathrm{PM}}$ & SS & $\mathrm{MHR}$ & APP & HPS & MHP & TP & PRRSV & PCV2 & SIV & \\
\hline $\begin{array}{l}\text { Total no. (\%) of samples in which } \\
\text { pathogens were detected }\end{array}$ & 1430 & $\begin{array}{l}240 \\
(16.8)\end{array}$ & $\begin{array}{l}251 \\
(17.6)\end{array}$ & $\begin{array}{l}199 \\
(13.9)\end{array}$ & $\begin{array}{l}130 \\
(9.1)\end{array}$ & $\begin{array}{l}110 \\
(7.7)\end{array}$ & $96(6.7)$ & $\begin{array}{l}47 \\
(3.3)\end{array}$ & $\begin{array}{l}715 \\
(50.0)\end{array}$ & $\begin{array}{l}456 \\
(31.9)\end{array}$ & $\begin{array}{l}49 \\
(3.4)\end{array}$ & $\begin{array}{l}323 \\
(22.6)\end{array}$ \\
\hline $\begin{array}{l}\text { Total no. (\%) of sample co-infected } \\
\text { with P. multocida }\end{array}$ & 240 & $\begin{array}{l}240 \\
(100)\end{array}$ & $48(20.0)$ & 46 (19.2) & $\begin{array}{l}34 \\
(14.2)\end{array}$ & $\begin{array}{l}24 \\
(10.0)\end{array}$ & $\begin{array}{l}25 \\
(10.4)\end{array}$ & $\begin{array}{l}11 \\
(4.6)\end{array}$ & $\begin{array}{l}147 \\
(61.3)\end{array}$ & $90(37.5)$ & $9(3.8)$ & - \\
\hline
\end{tabular}

${ }^{a}$ PM Pasteurella multocida, SS Streptococcus suis, MHR Mycoplasma hyorhinis, APP Actinobacillus pleuropneumoniae, HPS Haemophilus parasuis, MHP Mycoplasma hyopneumoniae, TP Trueperella pyogenes

${ }^{b} P R R S V$ porcine reproductive and respiratory syndrome virus, PCV2 porcine circovirus type 2, SIV swine influenza virus

${ }^{c}$ None, none of the respiratory pathogen was detected from pneumonic lungs 
Table 3 Distribution of biovars and capsular types among P. multocida isolates from 2008 to 2016

\begin{tabular}{|c|c|c|c|c|c|c|c|c|c|c|c|}
\hline \multirow[t]{2}{*}{ Biovar } & \multirow[t]{2}{*}{ Capsular type } & \multirow{2}{*}{$\begin{array}{l}\text { Total No. } \\
(\%)\end{array}$} & \multicolumn{9}{|c|}{ No. (\%) of positive isolates within the following years } \\
\hline & & & 2008 & 2009 & 2010 & 2011 & 2012 & 2013 & 2014 & 2015 & 2016 \\
\hline Biovar 1 & Cap F & $3(1.8)^{* * *}$ & 0 & 0 & 0 & 0 & 0 & 0 & $2(14.3)$ & $1(4.0)$ & 0 \\
\hline Biovar 2 & Cap A & $35(21.1)^{* * *}$ & $1(10.0)$ & 0 & $8(34.8)$ & $2(18.2)$ & $4(23.5)$ & $8(25.8)$ & $3(21.4)$ & $5(20.0)$ & $4(13.3)$ \\
\hline Biovar 3 & Cap A & $68(41.0)^{* * *}$ & $6(60.0)$ & $2(40.0)$ & $8(34.8)$ & $2(18.2)$ & $3(17.6)$ & $14(45.2)$ & $6(42.9)$ & $15(60.0)$ & $12(40.0)$ \\
\hline Biovar 3 & Cap D & $46(27.7)^{* * *}$ & $3(30.0)$ & $2(40.0)$ & $4(17.4)$ & $4(36.4)$ & $7(41.2)$ & $9(29.0)$ & $3(21.4)$ & $3(12.0)$ & $11(36.7)$ \\
\hline Biovar 13 & Cap A & $13(7.8)$ & 0 & 0 & $3(13.0)$ & $3(27.3)$ & $3(17.6)$ & 0 & 0 & $1(4.0)$ & $3(10.0)$ \\
\hline Biovar 13 & Cap D & $1(0.6)$ & 0 & $1(20.0)$ & 0 & 0 & 0 & 0 & 0 & 0 & 0 \\
\hline Total & & 166 & 10 & 5 & 23 & 11 & 17 & 31 & 14 & 25 & 30 \\
\hline
\end{tabular}

${ }^{* * *} P<0.001$

$h g b A$, $n a n B$, and $n a n H)$, whereas $t b p A$ was absent. Notably, the distribution of toxA (5.4\%), pfhA (22.9\%), $h s f-1$ (34.9\%), pmHAS (69.9\%), hgbB (78.3\%), and ptfA (99.4\%) varied among the 166 P. multocida isolates; this information and the distribution of virulence-associated genes according to capsular type and biovar are presented in Table 4. All capsular type A isolates harboured pmHAS $(P<0.001)$, and all capsular type D isolates harboured $h s f-1 \quad(P<0.001)$, with most $(97.9 \%)$ also harbouring $h g b B(P<0.001)$. Additionally, capsular type $\mathrm{F}$ (biovar 1$)$ was significantly correlated with $p f h A(P<0.01)$ and $h s f-1(P<$ $0.05)$. Notably, toxA was present in only $5.4 \%(n=9)$ of $P$. multocida isolates, which mainly belonged to biovar $3(n=9)$ and capsular type A $(n=8)$ (Table 4). Biovar 2 was highly associated with $p f h A$ and pmHAS, whereas biovar 3 was significantly correlated with $h s f-1, p m H A S$, and $h g b B(P<0.001$; Table 4). Most biovar 13 isolates harboured pmHAS and $h g b B$. The distribution of virulence-associated gene profiles of tox $A, h g b B$, and $p f h A$ in the different biovars is shown in Table 5 . All biovar 1 and 2 isolates were tox $A^{-} h g b B^{+} p f h A^{+}$and tox $A^{-} h g b B^{-} p f h A^{+}$, respectively $(P<0.001)$, with the $t o x A^{-} h g b B^{+} p f h A^{-}$profile present in most biovar $3(P<0.001)$ and all biovar $13(P<0.05)$ isolates.

\section{Antimicrobial susceptibility}

The antimicrobial-resistance patterns, cumulative minimum inhibitory concentrations (MICs), $\mathrm{MIC}_{50}$, and $\mathrm{MIC}_{90}$ of $P$. multocida isolates from diseased pigs are shown in Table 6. Of the 18 antimicrobials tested, isolates exhibited the highest level of resistance to oxytetracycline (63.3\%), followed by florfenicol (16.3\%), penicillin (9.0\%), ampicillin (7.8\%), trimethoprim-sulfamethoxazole (3.0\%), enrofloxacin (2.4\%), and tulathromycin (0.6\%), whereas all isolates were susceptible to ceftiofur and tilmicosin. The $\mathrm{MIC}_{90}$ values of antimicrobials for which breakpoints had not been determined according to Clinical and Laboratory Standards Institute (CLSI) criteria were as follows: chlortetracycline $(2 \mu \mathrm{g} / \mathrm{mL})$, spectinomycin $(32 \mu \mathrm{g} / \mathrm{mL})$, clindamycin $(16 \mu \mathrm{g} / \mathrm{mL})$, danofloxacin $(0.5 \mu \mathrm{g} / \mathrm{mL})$, gentamicin $(4 \mu \mathrm{g} / \mathrm{mL})$, neomycin $(16 \mu \mathrm{g} / \mathrm{mL})$, sulfadimethoxine $(\geq 512 \mu \mathrm{g} / \mathrm{mL})$, tiamulin $(32 \mu \mathrm{g} / \mathrm{mL})$, and tylosin $(32 \mu \mathrm{g} / \mathrm{mL})$.

\section{Discussion}

Our findings showed that $P$. multocida isolates were prevalent $(16.8 \%)$ in pig farms and the second most frequently isolated bacterial pathogen from diseased pigs, following S. suis (17.6\%). This was consistent with previous studies in Korea that reported the prevalence of $P$.

Table 4 Distribution of virulence-associated (VA) genes according to capsular type and biovar in 166 P. multocida isolates

\begin{tabular}{|c|c|c|c|c|c|c|c|c|}
\hline \multirow[t]{2}{*}{$V^{\prime}$ genes ${ }^{a}$} & \multicolumn{3}{|c|}{ No. (\%) of VA genes within the following capsular types } & \multicolumn{4}{|c|}{ No. (\%) of VA genes within the following biovars } & \multirow{2}{*}{$\begin{array}{l}\text { Total No. } \\
\text { (\% of } 166\end{array}$} \\
\hline & $\begin{array}{l}\text { Type A } \\
(69.9 \%, n=116)\end{array}$ & $\begin{array}{l}\text { Type D } \\
(28.3 \%, n=47)\end{array}$ & $\begin{array}{l}\text { Type F } \\
(1.8 \%, n=3)\end{array}$ & $\begin{array}{l}\text { Biovar } 1 \\
(1.8 \%, n=3)\end{array}$ & $\begin{array}{l}\text { Biovar } 2 \\
(21.1 \%, n=35)\end{array}$ & $\begin{array}{l}\text { Biovar } 3 \\
(68.7 \%, n=114)\end{array}$ & $\begin{array}{l}\text { Biovar } 13 \\
(8.4 \%, n=14)\end{array}$ & \\
\hline toxA & $8(6.9)$ & $1(2.1)$ & 0 & 0 & 0 & $9(7.9)^{*}$ & 0 & $9(5.4)$ \\
\hline pfhA & $35(30.2)^{* * *}$ & 0 & $3(100)^{* *}$ & $3(100)^{* *}$ & $35(100)^{* * *}$ & 0 & 0 & $38(22.9)$ \\
\hline$h s f-1$ & $8(6.9)^{* * *}$ & $47(100)^{* * *}$ & $3(100)^{*}$ & $3(100)^{*}$ & 0 & $54(47.4)^{* * *}$ & $1(7.1)^{*}$ & $58(34.9)$ \\
\hline pmHAS & $116(100)^{* * *}$ & 0 & 0 & 0 & $35(100)^{* * *}$ & $68(59.6)^{* * *}$ & $13(92.9)$ & $116(69.9)$ \\
\hline$h g b B$ & $81(69.8)^{* * *}$ & $46(97.9)^{* * *}$ & $3(100)$ & $3(100)$ & 0 & $113(99.1)^{* * *}$ & $14(100)^{*}$ & $130(78.3)$ \\
\hline ptfA & $116(100)$ & $46(97.9)$ & $3(100)$ & $3(100)$ & $35(100)$ & $113(99.1)$ & $14(100)$ & $165(99.4)$ \\
\hline
\end{tabular}

${ }^{*} P<0.05,{ }^{* *} P<0.01,{ }^{* * *} P<0.001$

${ }^{a}$ All isolates contained the following genes: oma87, psl, ompH, sodA, sodC, ExbBD-tonB, hgbA, nanB, nanH, hsf-2, plpB, fur, fimA, exbB. However, tbpA was not found in any of the isolates 
Table 5 Distribution of the toxA, hgbB, and pfhA gene profiles according to biovars

\begin{tabular}{|c|c|c|c|c|c|}
\hline \multirow{2}{*}{$\begin{array}{l}\text { Gene profile of } \\
\text { toxA/hgbB/pfhA }\end{array}$} & \multicolumn{4}{|c|}{ No. (\%) of gene profiles within the following biovars } & \multirow{2}{*}{$\begin{array}{l}\text { Total } \\
(n=166\end{array}$} \\
\hline & Biovar $1(n=3)$ & Biovar $2(n=35)$ & Biovar $3(n=114)$ & Biovar $13(n=14)$ & \\
\hline toxA $A^{-} h g b B^{+} p f h A^{+}$ & $3(100)^{* * *}$ & 0 & 0 & 0 & 3 \\
\hline tox $A^{-} h g b B^{-} p f h A^{+}$ & 0 & $35(100)^{* * *}$ & 0 & 0 & 35 \\
\hline tox $A^{+} h g b B^{+} p f h A^{-}$ & 0 & 0 & $9(7.9)^{*}$ & 0 & 9 \\
\hline tox $A^{-} h g b B^{+} p f h A^{-}$ & 0 & 0 & $104(91.2)^{* * *}$ & $14(100)^{*}$ & 118 \\
\hline tox $A^{-} h g b B^{-} p f h A^{-}$ & 0 & 0 & $1(0.9)$ & 0 & 1 \\
\hline
\end{tabular}

${ }^{*} P<0.05,{ }^{* * *} P<0.001$

multocida to be between 10 and $15.6 \%[7,8]$. The infections in this study comprised of a mix of $P$. multocida $(85.0 \%)$ with other respiratory pathogens, particularly PRRSV (61.3\%; $P=0.0001)$. Therefore, veterinary practitioners and surveillance stakeholders should consider coinfection with various pathogens that might exist in a given herd for PRDC control.

We characterised $166 P$. multocida isolates by determining their subspecies, biovar, capsular type, virulence-associated genes, and MIC. To the best of our knowledge, this is the first report of biovar prevalence in Korea. All isolates belonged to subspecies multocida, and the most prevalent type was biovar 3 (68.7\%), which is consistent with the results of previous studies of P. multocida recovered from pigs $[1,10,13]$. P. multocida biovar 1 is frequently isolated from poultry, but not pigs [1]. We found that the prevalence of biovar 13 was $8.4 \%$, which is slightly higher than that in other countries, such as Australia (2.0\%) and Hungary (4.8\%) [10, 11]. In agreement with numerous previous studies, the dominant P. multocida capsular types recovered from pneumonic pig lungs were capsular types A (69.9\%) and D (28.3\%) [1, $15,16,26]$. Additionally, capsular type B is the etiological cause of septicaemic pasteurellosis, whereas type $F$ is rarely reported in pigs $[1,14]$. Interestingly, capsular type F has been isolated in Korea post 2014, although at relatively low proportions $(n=3 ; 1.8 \%)$, the prevalence of which is consistent with that reported in other European studies [0.3\% (Germany), 1.0\% (UK), and 2.4\% (Spain)] [1, $2,16]$. A recent Chinese experimental study indicated that pig-origin capsular type $\mathrm{F}$ isolates are associated with porcine pneumonia and exhibit high pathogenicity in pigs [27]. Additionally, we found that P. multocida capsular type $\mathrm{F}$ was the only relevant respiratory pathogen isolated from three growing pigs with moderate-to-severe suppurative bronchopneumonia with fibrous/fibrinous

Table 6 Antimicrobial susceptibility and cumulative percentage of $P$. multocida isolates $(n=166)$ for 18 antimicrobials

\begin{tabular}{|c|c|c|c|c|c|c|c|c|c|c|c|c|c|c|c|c|c|c|c|}
\hline \multirow{2}{*}{ Antimicrobial } & \multicolumn{13}{|c|}{ Cumulative percentage of strains inhibited at antimicrobial concentration $(\mu \mathrm{g} / \mathrm{mL})$ of: } & \multirow{2}{*}{$\underset{(\mu \mathrm{g} / \mathrm{mL})^{\mathrm{a}}}{\mathrm{MIC}_{50}}$} & \multirow{2}{*}{$\underset{(\mu \mathrm{gIC} / \mathrm{mL})^{\mathrm{a}}}{\mathrm{MI}^{2}}$} & \multirow{2}{*}{$\mathrm{S}(\%)^{\mathrm{b}}$} & \multirow{2}{*}{$\mathrm{I}(\%)^{\mathrm{b}}$} & \multirow{2}{*}{$\mathrm{R}(\%)^{\mathrm{b}}$} & \multirow{2}{*}{$\begin{array}{c}\text { MIC Breakpoint } \\
(\mu \mathrm{gg} / \mathrm{mL})^{\mathrm{d}}\end{array}$} \\
\hline & $\leq 0.12$ & 0.25 & 0.5 & 1 & 2 & 4 & 8 & 16 & 32 & 64 & 128 & 256 & $\geq 512$ & & & & & & \\
\hline Oxytetracycline & & & 25.3 & 36.7 & 86.7 & 87.3 & 89.8 & 100 & & & & & & 2 & $\geq 16$ & 25.3 & 11.5 & 63.3 & $\geq 2$ \\
\hline Florfenicol & & 25.3 & 80.1 & 82.5 & & 83.7 & 100 & & & & & & & 0.5 & 8 & 82.5 & 1.2 & 16.3 & $\geq 8$ \\
\hline Penicillin & 69.3 & 90.4 & 91 & 92.2 & 92.8 & 93.4 & 100 & & & & & & & $\leq 0.12$ & 0.25 & 90.4 & 0.6 & 9.0 & $\geq 1$ \\
\hline Ampicillin & & 89.8 & 91.6 & 92.7 & 93.4 & 97 & 97.6 & & 100 & & & & & $\leq 0.25$ & 0.5 & 91.6 & 0.6 & 7.8 & $\geq 2$ \\
\hline \multicolumn{2}{|c|}{ Trimethoprim/sulfamethoxazole } & & & & 97 & 100 & & & & & & & & $\leq 2$ & $\leq 2$ & $\mathrm{ND}^{\mathrm{c}}$ & ND & 3.0 & $\geq 4 / 76$ \\
\hline Enrofloxacin & 87.3 & 93.4 & 97.6 & 98.8 & 100 & & & & & & & & & $\leq 0.12$ & 0.25 & 93.4 & 4.2 & 2.4 & $\geq 1$ \\
\hline Tulathromycin & & & & 81.9 & 97.6 & 99.4 & & & & 100 & & & & $\leq 1$ & 2 & 99.4 & 0 & 0.6 & $\geq 64$ \\
\hline Ceftiofur & & 99.4 & 100 & & & & & & & & & & & $\leq 0.25$ & $\leq 0.25$ & 100 & 0 & 0 & $\geq 8$ \\
\hline Tilmicosin & & & & & & 75.9 & 93.4 & 100 & & & & & & $\leq 4$ & 8 & 100 & 0 & 0 & $\geq 32$ \\
\hline Chlortetracycline & & & 18.7 & 44.6 & 91 & 98.8 & 100 & & & & & & & 2 & 2 & ND & ND & ND & - \\
\hline Spectinomycin & & & & & & & 8.4 & 85.5 & 92.8 & 94.6 & 100 & & & 16 & 32 & ND & ND & ND & - \\
\hline Clindamycin & & & & & & 3 & 31.3 & 100 & & & & & & 16 & 16 & ND & ND & ND & - \\
\hline Danofloxacin & 84.3 & 89.2 & 92.8 & 97.6 & 100 & & & & & & & & & $\leq 0.12$ & 0.5 & ND & ND & ND & - \\
\hline Gentamicin & & & & 10.2 & 65.1 & 91 & & 100 & & & & & & 2 & 4 & ND & ND & ND & - \\
\hline Neomycin & & & & & & 57.8 & 88.6 & 91 & 92.8 & 100 & & & & $\leq 4$ & 16 & ND & ND & ND & - \\
\hline Sulfadimethoxine & & & & & & & & & & & & 48.8 & 100 & $\geq 512$ & $\geq 512$ & ND & ND & ND & - \\
\hline Tiamulin & & & & & & 3 & 5.4 & 36.1 & 100 & & & & & 32 & 32 & ND & ND & ND & - \\
\hline Tylosin tartrate & & & & & & 3.6 & 19.9 & 68.1 & 100 & & & & & 16 & 32 & ND & ND & ND & - \\
\hline
\end{tabular}

The grey zone represents the tested concentration range of each antimicrobial provided in the BOPO6F plate

Susceptibility and resistance breakpoints are indicated by double vertical (sensitive) and single vertical (resistant) lines according to the guidelines of each reference ${ }^{\mathrm{a}} \mathrm{MIC}_{50}$ and $\mathrm{MIC}_{90}$, concentrations at which the growth of 50 and $90 \%$, respectively, of the isolates is inhibited

${ }^{\mathrm{b}} \mathrm{S}$ susceptible, I intermediate, $R$ resistant

${ }^{\mathrm{C}} \mathrm{ND}$ not determined

${ }^{\mathrm{d}}$ MIC breakpoints applied were those recommended by the Clinical and Laboratory Standards Institute (CLSI); trimethoprim/sulfamethoxazole interpretation was based on a previous study [25] 
pleuritis. This represents the first report identifying capsular type $\mathrm{F}$ isolates in Korea; therefore, the pathogenic significance of type $\mathrm{F}$ in pigs needs to be elucidated.

Virulence genotyping is a useful typing method for molecular characterisation of bacterial pathogens and has been previously applied to $P$. multocida $[1,3]$. Although oma87, ompH, plpB, psl, fimA, hsf-2, $\operatorname{sod} A, \operatorname{sod} C, \operatorname{exbB}$, $E x b B D$-tonB, fur, hgbA, nanB, nanH, and $p t f A$ were uniformly distributed among the isolates tested, none possessed $\operatorname{tbp} A$, which agreed with the results of previous pig studies $[1-3,17]$. The wide distribution of these genes indicates their importance for the survival of $P$. multocida within the host environment. Additionally, the virulence factors involved in cross-protection might constitute potential vaccine candidates, regardless of capsular type [3]. However, previous studies demonstrated that several non-uniformly distributed virulence-associated genes exhibit significant relatedness with specific capsular types [1, $3,8,17]$. As shown in Table 4, all capsular type A and D isolates harboured $p m H A S$ and $h s f-1$, respectively, and most type $\mathrm{D}$ isolates harboured $h g b B(P<0.001)$. In this study, capsular type $\mathrm{F}$ displayed virulence-associated gene profiles similar to those of capsular type D $\left(h s f-1^{+} h g b B^{+}\right)$, except for $p f h A$. Previous studies reported tox $A$ as clearly associated with type $\mathrm{D}[1,3,7,17]$; however, we found that only one of the 47 type $\mathrm{D}(2.1 \%)$ isolates and $6.9 \%$ of type A isolates harboured toxA. These results, however, are not significant because most of the isolates were from pneumonic lesions and not from turbinates with PAR. Similar to a previous report, distinct associations were observed between the virulence-associated gene profiles of $\operatorname{tox} A, h g b B$, and $p f h A$ and biovars, except for biovar 13 [1]. All biovar 1, 2, and 13 isolates exhibited tox $A^{-} h g b B^{+} p f h A^{+}(P<0.001)$, tox$A^{-} h g b B^{-} p f h A^{+}(P<0.001)$, and tox $A^{-} h g b B^{+} p f h A^{-}(P<0.05)$ profiles, respectively, and most biovar 3 isolates displayed a tox $A^{-} h g b B^{+} p f h A^{-}$profile $(P<0.001)$. Additionally, tox $A$ was found only in biovar 3 isolates (tox $\left.A^{+} h g b B^{+} p f h A^{-} ; P<0.05\right)$.

Swine diseases have become co-infected with immunosuppressive diseases, leading to antimicrobial treatment failure and frequent resistance occurrence. Treatment against $P$. multocida infections commonly includes broadspectrum antimicrobials [3]. In this study, beta-lactams (penicillin, ampicillin, and ceftiofur), macrolides (tulathromycin and tilmicosin), and fluoroquinolone (enrofloxacin) were found to be more effective than oxytetracycline and florfenicol. Therefore, these agents are recommended as empirical antimicrobials for the treatment of $P$. multocida infection. Tetracycline resistance has previously been reported in $P$. multocida isolates worldwide $[3,6,25,28$, 29]. Its prevalence in the present study was found to be $63.3 \%$, which is similar to the prevalence in China (58.0\%) and North America (53.4\%) $[3,28]$ but higher than that in Australia (28.0\%) and European countries (20.4\%).
Previous studies recommended the use of florfenicol for the treatment of infections caused by P. multocida, because florfenicol-resistance rates are very low $(0-2 \%)$ in China, North America, Australia, and Europe [6, 25]; however, the present study showed a relatively higher resistance (16.3\%). According to the Korea Animal Health Products Association, tetracyclines and florfenicol are the most commonly used antibiotics in Korean pig husbandry [30], with their frequent use reflected in the resistance rates in the present study. Based on the occurrence of high rates of tetracycline and florfenicol resistance, these antimicrobial agents should be used carefully and accompanied by susceptibility tests. Additionally, continuous surveillance of antimicrobial resistance in respiratory pathogens, including $P$. multocida, is required due to the increasing use of therapeutic antimicrobials and emergence of new resistant strains.

This study was conducted to determine the phenotypic and genotypic characteristics of swine P. multocida isolates in Korea. However, the collected samples cannot be representative of current $P$. multocida isolates in Korean swine farms, given that the number of isolates submitted annually varies, and the isolates used in this study originated from diagnostic samples with unknown antimicrobial-treatment history. However, a large-scale study for the characterisation of clinical lung samples of $P$. multocida isolates would sufficiently broaden the understanding of $P$. multocida as a respiratory pathogen.

\section{Conclusions}

This represents a comprehensive report of P. multocida isolates in pigs in Korea. Our findings provide scientific information for further research, including development of vaccine candidates and guidelines for antimicrobial use in veterinary medicine. Moreover, the low discriminatory power of phenotypic characterisation limits the scope of adequate epidemiological information; therefore, different genotyping techniques using pulsed-field gel electrophoresis or multilocus sequence typing might be required to further elucidate the epidemiology of P. multocida and its genetic relatedness.

\section{Methods}

\section{Bacterial isolation and identification}

In total, 1430 lung samples were collected from pigs (suckling pigs, 9\%; weaning pigs, 49\%; growing-finishing pigs, 23\%; and unknown, 19\%) with pneumonic gross lesions from 514 farms nationwide between 2008 and 2016. All lung samples were submitted to the Animal and Plant Quarantine Agency for differential diagnosis of porcine respiratory diseases, including APP, HPS, $S$. suis, T. pyogenes, MHP, MHR, PRRSV, PCV2, and SIV. Following gross and histopathologic examination, 
samples were cultured on 5\% sheep blood agar, chocolate agar (Asan Pharm. Co., Ltd., Seoul, Korea), and MacConkey agar (Becton Dickinson, Sparks, MD, USA) and then incubated aerobically at $37^{\circ} \mathrm{C}$ for $48 \mathrm{~h}$. Suspected mucoid and non-haemolytic colonies were subjected to Gram staining and biochemical identification using the VITEK II system (BioMérieux, Marcy l'Etoile, France). Identification was further confirmed by species-specific PCR assay for amplification of kmt1 (Table 1) [19]. All P. multocida isolates were stored at $-80^{\circ} \mathrm{C}$ until use to determine the subspecies, biovar, and capsular type. Previously reported methods were used to differentiate between $P$. multocida and other pathogens $[3,31,32]$.

\section{Subspecies and biovar determination}

The confirmed P. multocida isolates were classified into three subspecies (multocida, septica, and gallicida) based on sorbitol and dulcitol fermentation [9]. Additionally, isolates were assigned to one of the established biovars based on their ability to ferment carbohydrates (sorbitol, dulcitol, maltose, xylose, glucose, trehalose, lactose, and arabinose) and produce the ODC enzyme [10].

\section{PCR assay for capsular typing and virulence-associated gene detection}

$P$. multocida isolates were inoculated into brain-heart infusion broth (Becton Dickinson) and cultured for $18 \mathrm{~h}$. Genomic DNA was extracted using the QIAamp DNA mini kit (Qiagen, Hilden, Germany) according to manufacturer instructions. The capsular types of the isolates were determined by multiplex PCR using the capsule-specific primers shown in Table 1 [20]. PCR analysis of 21 virulence-associated genes, including oma87, ompH, $p l p B$, $p s l$, fimA, pfhA, ptfA, hsf-1, hsf-2, sodA, sodC, exbB, exbBD-tonB, fur, tbpA, hgbA, hgbB, nanB, nanH, pmHAS, and toxA (Table 1) [3, 17, 18, 21], was conducted as previously described. PCR amplification was performed using a Mastercycler ep Gradient S (Eppendorf, Hamburg, Germany), and amplified products were analysed with a capillary electrophoresis system (QIAxcel Advanced System; Qiagen). All tests were performed in duplicate in parallel with the relevant positive and negative controls.

\section{Antimicrobial-susceptibility testing}

The MIC of all isolates $(n=166)$ was determined using the standard broth microdilution method with the Sensititre system (TREK Diagnostic System; Thermo Fisher Scientific, Cleveland, OH, USA) and commercially prepared 96-well antimicrobial testing plates containing 18 different agents (BOPO6F; TREK Diagnostic Systems). The following antimicrobials were tested: penicillin, ampicillin, ceftiofur, florfenicol, gentamicin, neomycin, chlortetracycline, oxytetracycline, clindamycin, enrofloxacin, danofloxacin, trimethoprim/sulfamethoxazole, sulfadimethoxine, spectinomycin, tulathromycin, tylosin tartrate, tilmicosin, and tiamulin. Escherichia coli ATCC 25922 was tested for quality control purposes. As shown in Table 6, the MICs were interpreted according to CLSI guidelines for oxytetracycline, florfenicol, penicillin, ampicillin, enrofloxacin, tulathromycin, ceftiofur, and tilmicosin or those of a previous study describing analysis of trimethoprim/sulfamethoxazole, for which CLSI breakpoints were not available $[25,33]$. The overall $\mathrm{MIC}_{50}$ and $\mathrm{MIC}_{90}$ values (i.e., the lowest concentrations at which growth was inhibited by 50 and $90 \%$, respectively) for each antimicrobial were determined for all isolates.

\section{Statistical analysis}

Statistical testing was performed using GraphPad Prism (v5.01; GraphPad Software, San Diego, CA, USA) and SPSS (v22.0; IBM Corp., Armonk, NY, USA). Pearson's chisquared and Fisher's exact tests were used to assess associations among capsular types, biovars, and virulence-associated genes. A $P<0.05$ was considered statistically significant.

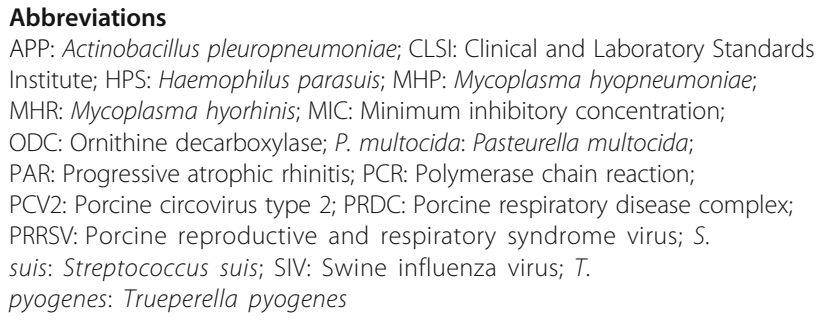
Institute; HPS: Haemophilus parasuis; MHP: Mycoplasma hyopneumoniae; MHR: Mycoplasma hyorhinis; MIC: Minimum inhibitory concentration; ODC: Ornithine decarboxylase; P. multocida: Pasteurella multocida; PAR: Progressive atrophic rhinitis; PCR: Polymerase chain reaction; PCV2: Porcine circovirus type 2; PRDC: Porcine respiratory disease complex; PRRSV: Porcine reproductive and respiratory syndrome virus; $S$. suis: Streptococcus suis; SIV: Swine influenza virus; $T$. pyogenes: Trueperella pyogenes

\section{Acknowledgements}

The authors would like to thank Yu-Ran Lee and Bun Seung Jo for their technical assistance.

\section{Funding}

This work was supported by a grant from the Animal and Plant Quarantine Agency, Ministry of Agriculture, Food and Rural Affairs of the Republic of Korea. The funding body had no role in the design of the study and collection, analysis, and interpretation of data and in writing the manuscript.

\section{Availability of data and materials}

The datasets generated or analysed during the current study are available from the corresponding author on reasonable request.

\section{Authors' contributions}

$\mathrm{JK}$ and $\mathrm{SIO}$ were involved in study design, performed sample collection, conducted laboratory work, and drafted the manuscript. JWK helped design the study and interpret the data. BS and WIK were involved in designing and analysing the data. HYK interpreted the data and wrote the manuscript. All authors reviewed the article and approved it.

\section{Ethics approval and consent to participate}

Non-experimental study has been performed on animals. Diagnostic investigation and additional characterisation have been conducted on samples that are submitted by veterinarians and pig owners. The specimens used in this research are field samples originating from natural respiratory symptoms and sent to our laboratory for official diagnosis. 


\section{Consent for publication}

Not applicable.

\section{Competing interests}

The authors declare that they have no competing interests.

\section{Publisher's Note}

Springer Nature remains neutral with regard to jurisdictional claims in published maps and institutional affiliations.

\section{Author details}

${ }^{1}$ Animal Disease Diagnostic Division, Animal and Plant Quarantine Agency, 177 Hyeoksin 8-ro, Gimcheon, Gyeongbuk 39660, Republic of Korea. ${ }^{2}$ Laboratory of Immunology, College of Veterinary Medicine, Chonbuk National University, Iksan 54596, Republic of Korea.

Received: 8 September 2018 Accepted: 3 April 2019

Published online: 25 April 2019

\section{References}

1. García N, Fernández-Garayzábal JF, Goyache J, Domínguez L, Vela Al. Associations between biovar and virulence factor genes in Pasteurella multocida isolates from pigs in Spain. Vet Rec. 2011;169:362.

2. Bethe A, Wieler LH, Selbitz HJ, Ewers C. Genetic diversity of porcine Pasteurella multocida strains from the respiratory tract of healthy and diseased swine. Vet Microbiol. 2009;139:97-105.

3. Tang X, Zhao Z, Hu J, Wu B, Cai X, He Q, Chen H. Isolation, antimicrobial resistance, and virulence genes of Pasteurella multocida strains from swine in China. J Clin Microbiol. 2009:47:951-8.

4. Fablet C, Marois C, Kuntz-Simon G, Rose N, Dorenlor V, Eono F, Eveno E, Jolly J, Le Devendec L, Tocqueville V, Quéguiner S, Gorin S, Kobisch M, Madec F. Longitudinal study of respiratory infection patterns of breeding sows in five farrow-to-finish herds. Vet Microbiol. 2011;147:329-39.

5. Opriessnig T, Giménez-Lirola LG, Halbur PG. Polymicrobial respiratory disease in pigs. Anim Health Res Rev. 2011;12:133-48.

6. Dayao DAE, Gibson JS, Blackall PJ, Turni C. Antimicrobial resistance in bacteria associated with porcine respiratory disease in Australia. Vet Microbiol. 2014;171:232-5.

7. Lee KE, Jeoung HY, Lee JY, Lee MH, Choi HW, Chang KS, Oh YH, An DJ. Phenotypic characterisation and random amplified polymorphic DNA (RAPD) analysis of Pasteurella multocida isolated from Korean pigs. J Vet Med Sci. 2012;74:567-73.

8. Lee KE, Choi HW, Jo HY, Kim HH, Yang DK. Pasteurella multocida isolation from pigs with respiratory disease in Korea. Korean J Vet Res. 2016;56:37-40.

9. Mutters R, Ihm P, Pohl S, Frederiksen W, Mannheim W. Reclassification of the genus Pasteurella Trevisan 1887 on the basis of deoxyribonucleic acid homology, with proposals for the new species Pasteurella dagmatis, Pasteurella canis, Pasteurella stomatis, Pasteurella anatis, and Pasteurella langaa. Int J Syst Bacteriol. 1985;35:309-22.

10. Blackall PJ, Pahoff JL, Bowles R. Phenotypic characterisation of Pasteurella multocida isolates from Australian pigs. Vet Microbiol. 1997;57:355-60.

11. Varga Z, Sellyei B, Magyar T. Phenotypic and genotypic characterisation of Pasteurella multocida strains isolated from pigs in Hungary. Acta Vet Hung. 2007;55:425-34.

12. Blackall PJ, Fegan N, Pahoff JL, Storie GJ, Mclntosh GB, Cameron RD, O'Boyle D, Frost AJ, Bara MR, Marr G, Holder J. The molecular epidemiology of four outbreaks of porcine pasteurellosis. Vet Microbiol. 2000;72:111-20.

13. Jamaludin R, Blackall PJ, Hansen MF, Humphrey S, Styles M. Phenotypic and genotypic characterisation of Pasteurella multocida isolated from pigs at slaughter in New Zealand. N Z Vet J. 2005;53:203-7.

14. Cardoso-Toset F, Gómez-Laguna J, Callejo M, Vela Al, Carrasco L, FernándezGarayzábal JF, Maldonado A, Luque I. Septicaemic pasteurellosis in freerange pigs associated with an unusual biovar 13 of Pasteurella multocida. Vet Microbiol. 2013;167:690-4.

15. Choi C, Kim B, Cho WS, Kim J, Kwon D, Cheon DS, Chae C. Capsular serotype, toxA gene, and antimicrobial susceptibility profiles of Pasteurella multocida isolated from pigs with pneumonia in Korea. Vet Rec. 2001;149:210-2.

16. Davies RL, MacCorquodale R, Baillie S, Caffrey B. Characterisation and comparison of Pasteurella multocida strains associated with porcine pneumonia and atrophic rhinitis. J Med Microbiol. 2003;52:59-67.
17. Ewers C, Lübke-Becker A, Bethe A, Kießling S, Filter M, Wieler LH. Virulence genotype of Pasteurella multocida strains isolated from different hosts with various disease status. Vet Microbiol. 2006;114:304-17.

18. Aski HS, Tabatabaei M. Occurrence of virulence-associated genes in Pasteurella multocida isolates obtained from different hosts. Microb Pathog. 2016;96:52-7.

19. Townsend KM, Frost AJ, Lee CW, Papadimitriou JM, Dawkins HJ. Development of PCR assays for species and type-specific identification of Pasteurella multocida isolates. J Clin Microbiol. 1998;36:1096-100.

20. Townsend KM, Boyce JD, Chung JY, Frost AJ, Adler B. Genetic organization of Pasteurella multocida cap loci and development of a multiplex capsular PCR typing system. J Clin Microbiol. 2001;39:924-9.

21. Atashpaz S, Shayegh J, Hejazi MS. Rapid virulence typing of Pasteurella multocida by multiplex PCR. Res Vet Sci. 2009;87:355-7.

22. Vera-Lizarazo YA, Rodríguez-Ferri EF, Martin de la Fuente AJ, GutiérrezMartín CB. Evaluation of changes in antimicrobial susceptibility patterns of Pasteurella multocida subsp. multocida isolates from pigs in Spain in 19871988 and 2003-2004. Am J Vet Res. 2006;67:663-8.

23. Nedbalcová K, Kučerová Z. Antimicrobial susceptibility of Pasteurella multocida and Haemophilus parasuis isolates associated with porcine pneumonia. Acta Vet. 2013;82:3-7.

24. De Jong A, Thomas V, Simjee S, Moyaert H, El Garch F, Maher K, Morrissey I, Butty $\mathrm{P}$, Klein $U$, Marion $H$, Rigaut D, Vallé M. Antimicrobial susceptibility monitoring of respiratory tract pathogens isolated from diseased cattle and pigs across Europe: the VetPath study. Vet Microbiol. 2014;172:202-15.

25. El Garch F, de Jong A, Simjee S, Moyaert H, Klein U, Ludwig C, Marion H, Haag-Diergarten S, Richard-Mazet A, Thomas V, Siegwart E. Monitoring of antimicrobial susceptibility of respiratory tract pathogens isolated from diseased cattle and pigs across Europe, 2009-2012: VetPath results. Vet Microbiol. 2016;194:11-22.

26. Rúbies $X$, Casal J, Pijoan C. Plasmid and restriction endonuclease patterns in Pasteurella multocida isolated from a swine pyramid. Vet Microbiol. 2002;84:69-78.

27. Peng Z, Liang W, Wang $Y$, Liu W, Zhang H, Yu T, Zhang A, Chen H, Wu $B$. Experimental pathogenicity and complete genome characterisation of a pig origin Pasteurella multocida serogroup $\mathrm{F}$ isolate HN07. Vet Microbiol. 2017;198:23-33.

28. Portis E, Lindeman C, Johansen L, Stoltman G. Antimicrobial susceptibility of porcine Pasteurella multocida, Streptococcus suis, and Actinobacillus pleuropneumoniae from the United States and Canada, 2001 to 2010. J Swine Health Prod. 2013;21:30-41.

29. Sweeney MT, Lindeman C, Johansen L, Mullins L, Murray R, Senn MK, Bade D, Machin C, Kotarski SF, Tiwari R, Watts JL. Antimicrobial susceptibility of Actinobacillus pleuropneumoniae, Pasteurella multocida, Streptococcus suis, and Bordetella bronchiseptica isolated from pigs in the United States and Canada, 2011 to 2015. J Swine Health Prod. 2017;25:106-20.

30. Anonymous. Establishment of antimicrobial resistance surveillance system for livestock. In: Animal and plant quarantine agency report (Korea). Gimcheon: Animal and Plant Quarantine Agency (APQA); 2016.

31. Jung JY, Jeong JH, Kim HY, Oh SI, Ryu DY, Yoon HL, So B, Yoon SS. A case of submandibular pyogranuloma caused by Trueperella pyogenes in the slaughtered dairy cows. Korean J Vet Serv. 2016;39:65-8.

32. Kim SH, Park JY, Jung JY, Kim HY, Park YR, Lee KK, Lyoo YS, Yeo SG, Park CK. Detection and genetic characterization of porcine circovirus 3 from aborted fetuses and pigs with respiratory disease in Korea. J Vet Sci. 2018;19:721-4.

33. CLSI, editor. Performance Standards for Antimirobial Disk and Dilution Susceptibility Tests for Bacteria Isolated From Animals. 3rd ed. CLSI supplement VET01S. Wayne: Clinical and Laboratory Standards Institute; 2015.

\section{Ready to submit your research? Choose BMC and benefit from:}

- fast, convenient online submission

- thorough peer review by experienced researchers in your field

- rapid publication on acceptance

- support for research data, including large and complex data types

- gold Open Access which fosters wider collaboration and increased citations

- maximum visibility for your research: over $100 \mathrm{M}$ website views per year

At $\mathrm{BMC}$, research is always in progress.

Learn more biomedcentral.com/submissions 